\title{
PEMANFAATAN LIMBAH SERABUT KELAPA DI DESA KORLEKO KECAMATAN LABUHAN HAJI KABUPATEN LOMBOK TIMUR
} \author{
Trisno Kurniawan ${ }^{4}$, Intan Tamara Pitaloka ${ }^{5}$, lin Indriani ${ }^{5}$, Anindia Safitri ${ }^{5}$, Elma Ramdhani ${ }^{5}$, dan \\ Fahruddin ${ }^{4}$ \\ ${ }^{1}$ Fakultas Pertanian Universitas Mataram \\ ${ }^{2}$ Fakultas Teknik Universitas Mataram \\ ${ }^{3}$ Fakultas Hukum Universitas Mataram \\ ${ }^{4}$ Fakultas Keguruan dan IImu Pendidikan Universitas Mataram \\ ${ }^{5}$ Fakultas Ekonomi dan Bisnis Universitas Mataram \\ ${ }^{*}$ Co-Author : Fahruddin@unram.ac.id
}

Ahmad Ardian Ariatma ${ }^{1}$, Abdul Kadir ${ }^{1}$, Emi Setiarini ${ }^{2}$, Melania Sindy Gunarsih ${ }^{3}$, Novel Saputra ${ }^{4}$,

\begin{abstract}
ABSTRAK. Kelapa merupakan salah satu sumber pendapatan ekonomi masyarakat Desa Korleko. Desa Korleko terkenal sebagai salah satu penghasil kelapa terbesar di Pulau Lombok, namun saat ini potensi kelapa tersebut belum dimanfaatkan secara optimal. Kelapa dijual tanpa melalui proses pengolahan terlebih dahulu. Jika dilakukan pengolahan kelapa terlebih dahulu sebelum dilakukan pemasaran maka nilai jual kelapa akan meningkat. Serabut kelapa adalah hasil produk sampingan dari kelapa yang menjadi limbah dan kurang dimanfaatkan. Serabut kelapa dapat diolah menjadi cocofiber (serat sabut kelapa) dan cocopeat (serbuk sabut kelapa atau gabus) yang dapat di manfaatkan menjadi berbagai produk diantaranya serabut kelapa menjadi keset, sapu, isi bantal dan media tanam holtikultura, serta masih banyak lagi. Semua produk tersebut dapat diproses dengan mudah oleh masyarakat dan memiliki nilai ekonomi yang tinggi sehingga dapat meningkatkan ekonomi masyarakat.
\end{abstract}

Kata kunci : Kelapa, Limbah Serabut Kelapa, cocofiber, cocopeat, Desa Korleko

\begin{abstract}
Coconut is a source of economic income for the people of Korleko Village. Korleko village is famous as one of the biggest coconut producers on Lombok Island, but at present the potential of coconut has not been used optimally. Coconut is sold without going through the processing first. If coconut processing is carried out prior to marketing, the selling value of coconuts will increase. Coconut fiber is a byproduct of coconut which is waste and is underused. Coconut fiber can be processed into cocofiber (coconut fiber) and cocopeat (coconut fiber powder or cork) which can be utilized as various products including coconut fibers into mats, brooms, pillow contents and horticultural planting media, and many more. All of these products can be processed easily by the community and have high economic value so as to improve the community's economy.
\end{abstract}

Keywords: Coconut, Coconut Fiber Waste, cocofiber, cocopeat, Korleko Village

\section{PENDAHULUAN}

Kelapa merupakan salah satu tumbuhan yang dapat hidup di iklim tropis seperti Indonesia. Semua bagian dari pohon kelapa dapat dimanfaatkan menjadi suatu yang lebih berharga. Di Indonesia dikenal memiliki luas perkebunan kelapa terbesar di dunia yaitu 3.712 juta ha, sebagian besar merupakan perkebunan rakyat $(96,9 \%)$ sisanya milik negara $(0,7 \%)$ dan swasta $(2,7 \%)$. Potensi produksi sebesar 15 milyar butir pertahun ternyata baru dimanfaatkan sebesar 7,5 milyar butir pertahun atau sekitar 50\% dari potensi produksi. (Fahruddin., et.all, 2018). 
Pengolahan hasil buah kelapa terutama produk turunannya masih memiliki peluang yang cukup besar. Saat ini industri pengolahan buah kelapa umumnya masih terfokus kepada pengolahan hasil daging buah sebagai hasil utama, sedangkan industri yang mengolah hasil samping buah (by product) seperti air, sabut, dan tempurung kelapa masih diolah secara tradisional. (Indahyani, 2011)

Pada saat yang sama, Indonesia hanya mengekspor satu jenis produk (berupa serat mentah) dengan volume 102 ton. Angka ini menurun tajam dibandingkan ekspor tertinggi pada tahun 1996 yang mencapai 866 ton (Ditjenbun, 2002; BPS, 2002).

Berdasarkan data dari e-smartschool, sabut kelapa (cocofiber) merupakan bagian yang cukup besar dari buah kelapa, yaitu $35 \%$ dari berat keseluruhan buah. Sabut kelapa terdiri dari serat dan gabus yang menghubungkan satu serat dengan serat lainnya. Serat adalah bagian yang berharga dari sabut. Setiap butir kelapa mengandung serat 525 gram (75\% dari sabut), dan gabus 175 gram (25\% dari sabut). Produksi buah kelapa Indonesia rata-rata 15,5 milyar butir/tahun atau setara dengan 1,8 juta ton serat sabut, dan 3,3 juta ton debu sabut (Agustian, et al., 2003; Allorerung \& Lay, 1998; Anonim, 2000; Nur, et al., 2003; APCC, 2003).

Dilihat dari persentase komponennya, buah kelapa terdiri dari 35\% sabut kelapa, $12 \%$ tempurung, 28\% daging kelapa, 25\% air kelapa. Dari persentase tersebut bisa dibayangkan berapa banyak limbah sabut kelapa yang bisa dihasilkan dari kegiatan pengolahan kelapa, dan hal ini bisa meningkatkan perekonomian masyarakat dengan cara mengoptimalkan manfaat dari sabut kelapa itu sendiri. (Anggoro, 2009).

Pemanfaatan cocofiber ini bisa dijadikan berbagai macam produk, salah satu yang bisa kita hasilkan adalah membuat isi bantal menggunakan cocofiber yang di berikan juga aroma terapi.

Pada pembuatan isi bantal beraroma terapi diberikan pelatihan mengenai proses pembuatan produk ini, mulai dari merendam sabut kelapa, mengambil cocofiber yang terpisahkan dengan kulit kelapa sampai dengan memasukkan cocofiber yang sudah bersih ke dalam bantal. (Hartini, 2013).

Motif bantal yang dibuat haruslah menarik dan unik sehingga bukan hanya menjadi bantal tidur biasa. Menariknya motif dan bentuk bantal ini nantinya diharapkan bisa menarik minat pembeli. Dengan seperti itu maka pemanfaatan limbah sabut kelapa bisa di optimalkan untuk meningkatkan perekonomian masyarakat sehingga sesuai dengan tujuan program kerja yang dilakukan.

Cocopeat adalah serbuk sabut kelapa yang dihasilkan dari proses memisahkan cocofiber dengan kulit kelapa, sehingga dihasilkan serbuk kelapa yang bisa dimanfaatkan untuk berbagai macam produk. Salah satunya adalah dengan menjadikan cocopeat sebagai media untuk tanaman Hortikultura. Cocopeat mengandung kalium (K), fosfor $(P)$ Nitrogen $(N)$, Tembaga $(C u)$, Boron (B), Klorin ((Cl), Besi (Fe), Kasium (Ca), Magnesium (Mg) dan Seng ( $\mathrm{Zn})$, dengan kandungan unsure hara yang banyak tersebut maka cocopeat bisa dijadikan media alternatif pengganti serbuk kayu untuk budidaya jamur tiram. (Pratiwi 2013).

Media tanam diartikan sebagai tempat tinggal bagi tanaman. Media tanam yang termasuk dalam kategori bahan organik umumnya berasal dari komponen organisme hidup, misalnya bagian dari tanaman seperti daun, batang, bunga, buah, atau kulit kayu. Penggunaan bahan organik sebagai media tanam jauh lebih unggul dibandingkan dengan bahan anorganik. Hal itu dikarenakan bahan organik sudah mampu menyediakan unsur-unsur hara bagi tanaman. Selain itu, bahan organik juga memiliki pori-pori makro dan mikro yang hampir seimbang sehingga sirkulasi udara yang dihasilkan cukup baik serta memiliki daya serap air yang tinggi. (Wiryanta BTW 2008).

Jamur tiram (Pleurotus ostreatus) adalah kelompok jamur pangan yang aman di konsumsi oleh manusia. Di alam bebas, jamur tiram bisa dijumpai hampir sepanjang tahun di hutan pegunungan daerah yang sejuk. Tubuh buah terlihat saling bertumpuk di permukaan batang pohon yang sudah melapuk atau pokok batang pohon yang sudah ditebang karena jamur tiram adalah salah satu jenis jamur kayu. Untuk itu, saat ingin membudidayakan jamur ini, substrat yang dibuat harus memperhatikan habitat alaminya. Media yang umum dipakaiuntuk membiakkan jamur tiram adalah 
serbuk gergaji kayu yang merupakan limbah dari penggergajian kayu. Alternatif lainnya bisa menggunakan cocopeat yang merupakan produk yang dihasilkan oleh serabut kelapa. (Cahyana 1999).

\section{METODE PELAKSANAAN}

\section{Waktu dan Tempat}

Kegiatan dilakukan selama 45 Hari mulai dari pertengahan bulan Juli sampai pertengahan bulan September di Desa Korleko Kecamatan Labuhan Haji Kabupaten Lombok Timur Nusa Tenggara Barat.

\section{Alat dan Bahan}

Alat yang digunakan pada program ini adalah mesin pemisah serabut kelapa (gambar 1), panci besar, sekop, botol, sendok bibit, kantong plastik, cincin plastik dan tutup cincin plastik. sedangkan bahan yang digunakan adalah cocofiber (serat), kayu manis,cocopeat (serbuk sabut kelapa), kapur (CaCO3) dan bekatul (dedak).

\section{PEMBAHASAN}

\section{PROSES PEMBUATAN ISI BANTAL SERABUT KELAPA BERAROMA TERAPI}

\section{Pertama: Pemisahan}

Hal yang pertama yang harus dilakukan adalah melakukan modifikasi serabut kelapa. Jika Anda ingin menggunakan serabut kelapa dalam jumlah yang banyak, bisa dilakukan dengan menggunakan mesin pengupas serabut kelapa (gambar 1).

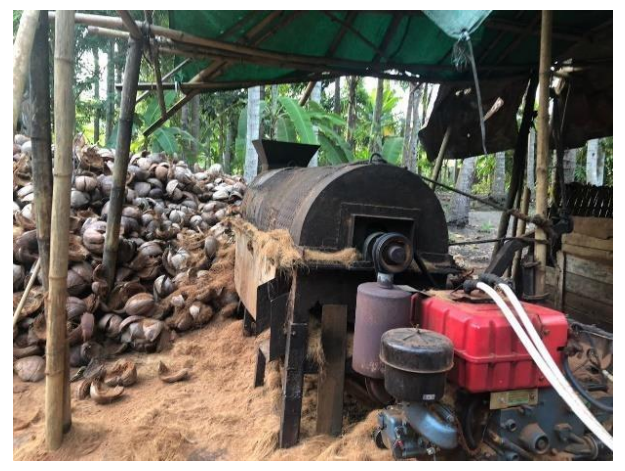

Gambar 1. Proses Pemisahan Serabut Kelapa dengan Menggunakan Mesin

\section{Kedua: Pem-filter-an}

Serabut kelapa yang sudah melalui proses pemisahan dengan kulit luarnya kemudian akan melalui proses pemfilteran. Proses ini dilakukan dengan cara memilih serabut kelapa dengan tekstur paling lembut untuk dijadikan isi bantal. Proses pemfilteran ini dikerjakan secara manual (gambar 2). 


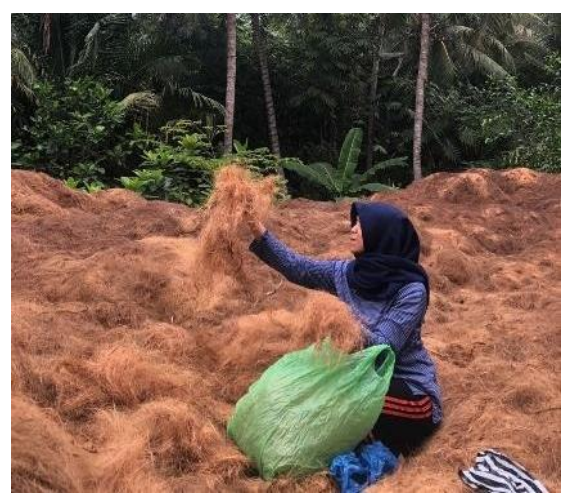

Gambar 2. Proses Pem-filter-an Serabut Kelapa secara manual

\section{Ketiga: Pemutihan (bleaching)}

Proses pemutihan ini dilakukan untuk menghilangkan warna coklat pada serabut kelapa yang sudah di filter dengan cara merendam serabut kelapa dan direbus dengan kayu manis sambil diaduk-aduk hingga tidak terjadi perubahan warna lagi. Proses bleaching ini dilakukan sampai warna berubah menjadi kuning kecoklatan.

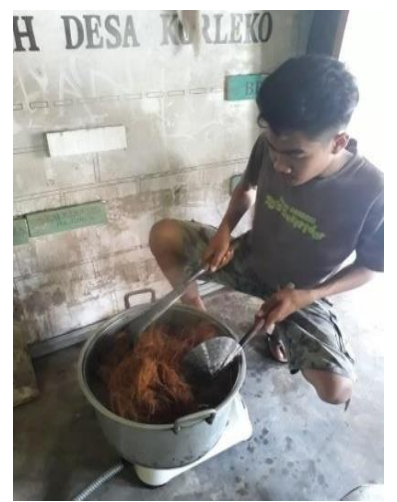

Gambar 3. Proses Pemutihan (bleaching)

\section{Keempat: Pengeringan (drying)}

Tujuan dari proses pengeringan ini adalah untuk menghilangkan minyak yang ada di dalam serabut. Proses pengeringan dilakukan dengan mengeringkan serabut langsung dibawah sinar matahari. Pengeringan ini dilakukan selama 1-2 hari.

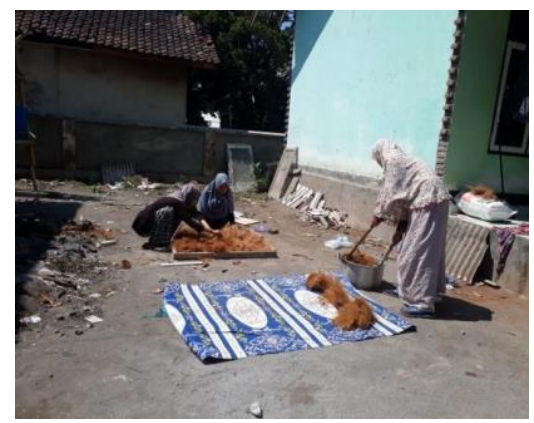

Gambar 4 Proses Pengeringan (drying) 


\section{Kelima: Finishing}

Serabut kelapa yang sudah melalui proses pengeringan akan dimasukkan ke dalam sarung bantal yang sudah disiapkan. Sarung bantal dapat dibentuk dengan berbagi bentuk dan ukuran sesuai selera. Proses finishing ini dilakukan dengan cara memasukkan serat kelapa sedikit demi sedikit ke dalam sarung bantal, kemudian dilanjutkan dengan memasukkan beberapa potongan kayu manis dan jahit pada bagian yang telah digunakan untuk memasukkan serabut tersebut.
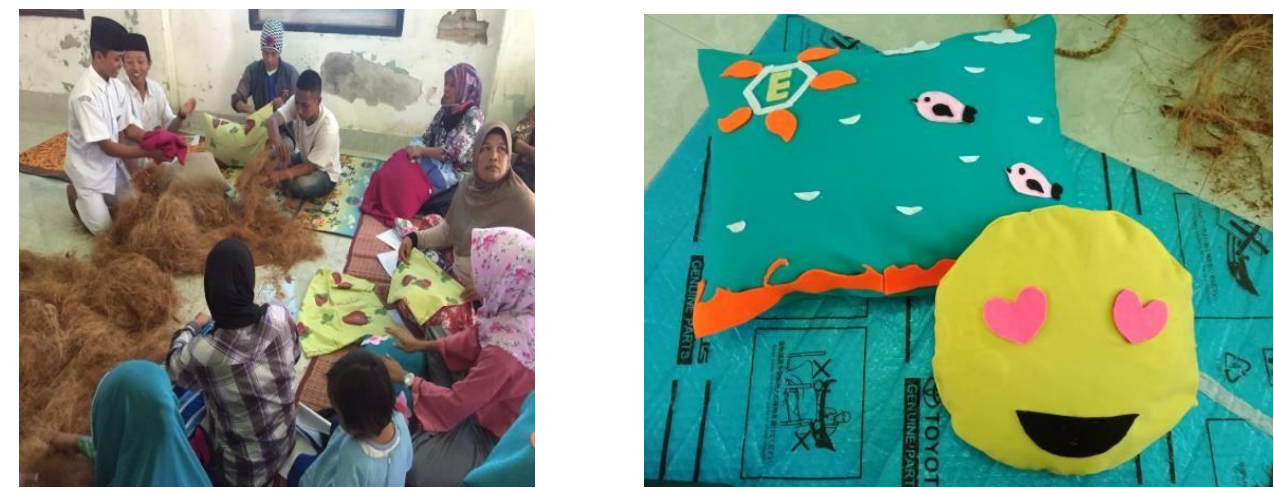

Gambar 5. Proses Finishing \& Produk Akhir Bantal

\section{PROSES PEMBUATAN MEDIA TANAM JAMUR TIRAM}

\section{Pertama: Pengayakan}

Proses pengayakan merupakan proses pertama untuk memisahkan serabut kelapa dengan kulit yang akan menghasilkan cocoopeat. Teknik pemisahan ini dapat menggunakan metode tradisional dan modern.

\section{Kedua: Persiapan Bahan}

Proses kedua adalah periapan bahan - bahandiantaranya seperti, bekatul, cocopeat dan kapur.

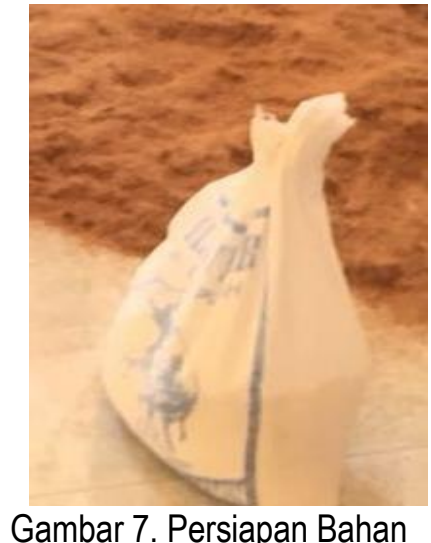




\section{Ketiga: Pencampuran}

Proses pencampran bahan dilakukan dengan mencampurkan bahan- bahan yang telah ditimbang sesuai dengan kebutuhan dicampur dengan cocopeat selanjutnya disiram dengan air sekitar 50 $60 \%$ atau bila kita kepal serbuk tersebut menggumpal tapi tidak keluar air. Hal ini menandakan kadar air sudah cukup.

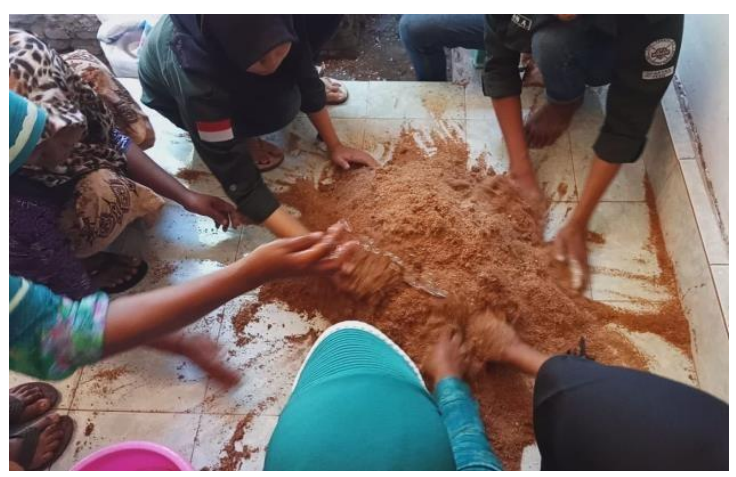

Gambar 8. Proses Percampuran

\section{Keempat: Pengomposan}

Pengomposan dilakukan dengan menutup bahan-bahan yang sudah dicampur tersebut dengan terpal ataupun bahan lainnya. Yang tujuannya untuk melapukkan bahan tersebut.

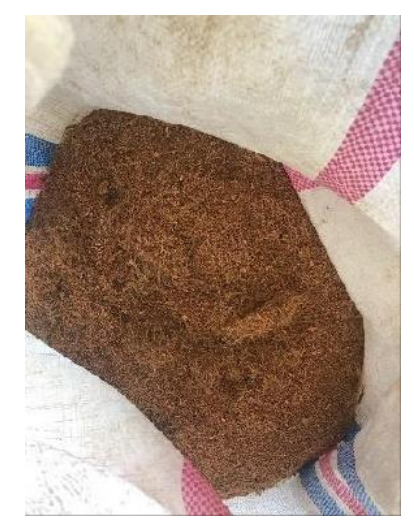

Gambar 9. Proses Pengoposan

\section{Kelima: Pembungkusan}

Pembungkusan menggunakan plastik polipropilen dengan ukuran yang dibutuhkan. Cara membungkus yaitu dengan memasukkan media ke dalam plastik kemudian dipukul pukul/ditumbuksampai padat dengan botol atau menggunakan filler (alat pemadat) kemudian disimpan. 


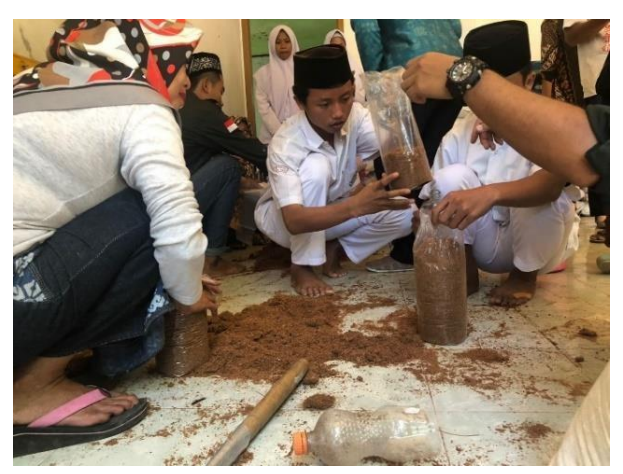

Gambar 10. Proses Pembungkusan

\section{Keenam: Sterilisasi}

Sterilisasi menggunakan alat sterilizer yang bertujuan untuk membasi mikroorganisme, seperti kapang, bakteri, khamir ataupun mikroba lain yang bisa saja mengganggu pertumbuhan jamur yang ditanam. Sterilisasi dilakukan pada suhu $90-100^{\circ} \mathrm{C}$ selama $4-12$ jam.

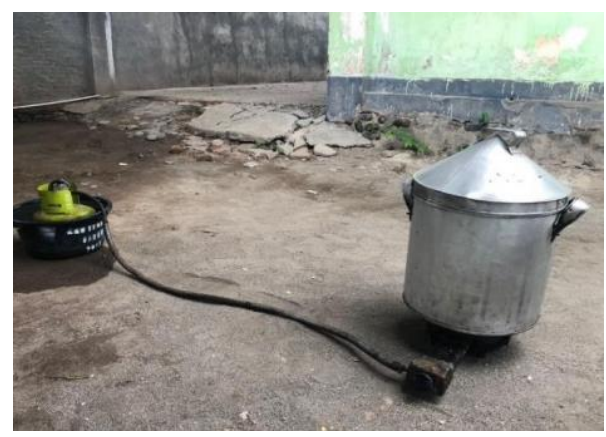

Gambar 11. Proses Sterilisasi

\section{Ketujuh: Inokulasi (Pembibitan Jamur)}

Proses inkulasi merupakan proses pembibitan jamur dengan cara baglog yang sudah disteriliasasi didinginkan, kemudian menanam dengan bibit jamur tiram dengan menggunakan sendok bibit sekitar 2 sendok bibit baglog tersebut.

\section{Kedelapan: Inkubasi}

Inkubasi jamur dilakukan dengan cara menyimpan baglog yang sudah dibibit pada ruangan inkubasi agar bisa tumbuh dengan optimal. Inkubasi dilakukan sampai seluruh baglog berubah warna menjadi putih yang disebabkan oleh tumbuhnya miselium jamur pada media

\section{KESIMPULAN}

Berdasar pemaparan di atas, diperoleh beberapa poin penting kesimpulan pengabdian kepada masyarakat ini yaitu sebagai berikut.

1. Sabut kelapa adalah adalah salah satu limbah yang dihasilkan dari pengolahan buah kelapa, sabut kelapa menjadi bagian terbesar dari buah kelapa yaitu mencapai 35\%. 
2. Cocofiber adalah serat sabut kelapa yang dihasilkan setelah proses pemisahan antara sabut kelapa dengan kulitnya.

3. Produk yang dihasilkan dari cocofiber ini bermacam-macam, salah satunya adalah bantal srabut kelapa aroma terafi

4. Cocopeat adalah limbah yang dihasilkan dari proses pengambilan serat sabut kelapa

5. Cocopeat banyak mengandung unsur makro maupun mikro untuk pertumbuhan dan perkembangan tanaman, sehingga bisa dijadikam sebagai media tanam tanaman hortikultura, selain itu bisa juga dijadikan sebagai media tanam alternative pengganti serbuk kayu untuk budidaya jamur tiram.

\section{DAFTAR PUSTAKA}

Agustian, A., Friyatno, S., Supadi, \& Askin, A. 2003. Analisis pengembangan agroindustri komoditas perkebunan rakyat (kopi dan kelapa) dalam mendukung peningkatan daya saing sektor pertanian. Makalah Seminar Hasil Penelitian Pusat Penelitian dan Pengembangan Sosial Ekonomi Pertanian Bogor. T.A. 2003. 38 hal

Allorerung, D., \& Lay, A. 1998. Kemungkinan pengembangan pengolahan buah kelapa secara terpadu skala pedesaan. Prosiding Konferensi Nasional Kelapa IV. Bandar Lampung 21 - 23 April 1998 Pp.327 - 340.

Anonim. 2000. Hasil pengkajian sabut kelapa sebagai hasil samping. Jakarta: Bank Indonesia. 15 hal.

APCC. 2003. Coconut statistical yearbook 2002. Asia Pacific Coconut Community.

Amin, Muh dan Samsudi. 2010. Pemanfaatan Limbah Serat Serabut Kelapa Sebagai Bahan Pembuat Helm Pengendara Kendaraan Roda Dua. Program Studi teknik Mesin Fakultas Teknik Universitas Muhammadiyah Semarang.

Anggoro, N.P. 2009. Hasil Samping Tanaman Kelapa. Tabloid Sinar Tani edisi 22-28 april 2009.

Cahyana, Mukhroji, dan M. Bakrum,1999. Pembibitan, Pembudidayaan, da Analisis Usaha dan Budidaya Jamur Tiram. Penebar Swadaya. Jakarta.

Fahruddin, dkk. 2018. Meningkatkan Kesejahteraan Masyarakat Melalui Pendidikan dan Pelatihan Pemafaatan Potensi Sumber Daya Alam Desa Korleko Lombok Timur. Mataram: CV Arga Puji.

Hartini,S., A.B. Wijaya, N. Widjojo, M. Sosilowati, dan G.Petriana. 2013. Pemanfaatan Serabut Kelapa Termodifikasi Sebagai Bahan Pengisi Bantal dan Matras. Prosiding seminar nasional sains dan pendidikan sain VII Fakultas Sains dan Matematika, UKSW. Salatiga

Indahyani, Titi. 2011. Pemanfaatan Limbah Sabut Kelapa Pada Perencanaan Interior dan Furniture yang Berdampak Pada Pemberdayaan Masyarakat Miskin. Humaniora. Vol. 2 No. 1. Hal 1 - 9

Pratiwi, Wiwit Sri Werdi. 2013. Pemanfaatan Sabut Kelapa Sebagai Media Pertumbuhan Alternatif Pada budidaya Jamur Tiram (Pleurotus ostretus). Skripsi. Institut Teknologi Sepuluh November.

Sunanik. 2013. Penguatan Ekonomi Kreatif Dan Inovatif Berbasis Sumberdaya Desa Besuki Di, Kecamatan Besuki Tulungagung. STKIP PGRI TULUNGAGUNG.

Wiryanta BTW 2008. Media Tanam untuk Tanaman Hias Jakarta: Agromedia Pustaka. 